\title{
La existencia de la ironía como ironía de la existencia Una investigación sobre el sentido
}

\author{
JOSÉ LUIS RAMÍREZ \\ Estocolmo
}

Resumen. El trabajo que aquí se presenta arranca de la tesis de que la Retórica no es un arte restringido a ciertas situaciones lingüísticas, sino una auténtica teoría del conocimiento y de la expresión humanas. El hombre es fundamentalmente un animal retórico. El fenómeno de la ironía no es un mero tropo, sino el indicador de que el ser humano sólo puede conocer y expresarse desviadamente, a través de un elemento sígnico. Y los tropos de la metáfora y la metonimia no son adornos añadidos al lenguaje reservados a ocasiones concretas, sino los mecanismos fundamentales de toda expresión lingüística, es decir, de toda encarnación del sentido en la palabra.
AbSTRACT. This work starts from the thesis that Rhetoric is most properly understood as an authentic theory of knowledge, not as an art form restricted to specific linguistic situations - man is essentially a rhetoric animal. It follows that irony functions not merely as a rhetorical trope in the narrow sense, but as the only way in which human beings can know and express themselves. Human communication is essentially indirect and devious, acts of signification. Metaphor and metonymy are not simply ornaments to be used in concrete situations, but crucial mechanisms in all modes of linguistic expression, a process of incarnation through which meaning turns to word.

\section{Presentación y marco}

Este ensayo se propone desarrollar fundamentalmente tres tesis:

1. La ironía significa la condición existencial humana como ser en el mundo.

2. El discurso sobre la ironía es un discurso de antropología.

3. No hay antropología sin tropología

Adviértase que el título del ensayo no es «La existencia de la ironía $y$ la ironía de la existencia», sino «La existencia de la ironía como ironía de la existencia». El enlace de los dos elementos del quiasmo de mi título mediante el comparativo «como» es significativo, siendo quizá la palabra puente «como» la piedra clave del enfoque de mi exposición. Pues siendo la ironía, como trataré de hacerles ver, la fuente arcana del lenguaje humano en general, el comparativo «como», que representa la igualdad de lo diferente, es una categoría gramatical y semántica directamente emanada de dicha fuente. 
La ironía anida y deja su huella en el vocabulario de una lengua. Palabras hay cuya función es, como en política, restringir la aserción que se está haciendo o incluso significar lo contrario de lo que dicen. Escribe Severo Catalina que «no hay cosa más incierta que la edad de las señoras que se dicen de cierta edad». Y decimos «seguramente» cuando estamos todo menos seguros de algo. Tampoco hay seguramente palabra más socrática que la palabra «quizá».

Estableciendo una comparación entre las dos interpretaciones de la ironía históricamente más destacadas, dice Jankelevitch ${ }^{1}$ que «mientras la sabiduría socrática desconfía tanto del conocimiento de sí mismo como del conocimiento del mundo y llega al saber de su propia ignorancia, la ironía romántica aniquila el mundo para tomarse más en serio a sí misma». Se me hace, sin embargo, difícil afiliarme a uno u otro de esos dos polos. Quizá me parezco más (sin saberlo) a los románticos, pero me identifico (a sabiendas) más con la postura socrática. Y como los españoles nos quedamos solos exagerando, simpatizo con aquel hispanoportugués, emigrado como yo (me refiero a Francisco Sánchez), que, más socrático que Sócrates, comenzaba su libro Quod nihil scitur («Que nada se sabe») diciendo: «Ni esto siquiera sé, que nada sé».

Es la ironía tema escurridizo, imposible de tratar sistemáticamente. Los estudios extensos, menos aún exhaustivos, sobre ella son pocos y bien conocidos. No es, sin embargo, mi intención suscitar aquí esos nombres y sus enfoques. Pues es costumbre de los profesionales españoles de filosofía el disertar más sobre lo que otros pensadores han dicho que sobre lo que ellos mismos sostienen. Extraña actitud irónica ésta. Pues aun cuando revela inseguridad acerca de la propia opinión, finge, sin embargo, estar al corriente de la opinión de toda una serie de autores, cosa que es todavía más problemática. Rompiendo con esta costumbre de hablar inseguramente de la inseguridad de otros, voy a tratar de hacer una aportación, modesta y también insegura, pero original, tratando de articular más bien lo que he asimilado que lo que he acumulado. Siempre me gustaron aquellas palabras de Antonio Machado en su autorretrato: «Dejar quisiera mi verso, como deja el capitán su espada: famosa por la mano viril que la blandiera, no por el docto oficio del forjador preciada».

Sí me anima, y quiero declararlo, un cierto espíritu aristotélico que me inculcó, hace más de treinta años, en aquella facultad matritense, el maestro Aranguren. Es también una ironía del destino que ninguno de los discípulos de Aranguren, que integran una familia numerosa de filósofos morales y políticos, se haya adscrito a la línea aristotélica, de la cual hasta parecen avergonzarse. Yo, en cambio, vástago disidente y emigrado de la familia aranguriana, que abandoné la filosofía como asignatura profesional y como conocimiento cumulativo para dedicarme a la práctica de la filosofía en otros terrenos sobre base asimilativa y experiencial, he seguido fiel a aquello que aprendí irónicamente, es decir, entre líneas, de las lecciones del profesor Aranguren.

${ }^{1}$ Wladimir Jankelevitch, La ironía, trad. de Ricardo Pochtar, Madrid, Taurus, 1982. 
El trabajo más original sobre la ironía se debe seguramente a Kierkegaard ${ }^{2}$, cuya tesis doctoral de 1841 se titulaba justamente «Sobre el concepto de ironía». Pues bien, más que del concepto de la ironía quiero yo ocuparme de la ironía del concepto. Y así como Wayne C. Booth (1974) ha escrito un magnífico libro sobre la retórica de la ironía, mi propio interés se ve atraído por la ironía de la retórica.

Conocemos, en efecto, la ironía principalmente a través de la retórica, la cual es para mí algo más profundo que un arte de elegancia y convencimiento. Nietzsche decía con todo acierto que las figuras retóricas son la esencia del lenguaje. En esa línea (y no porque lo dijera Nietzsche) vengo yo trabajando desde 1989, fecha en que hube de abordar (en el Seminario estival de Antropología de la Conducta que Carlos Castilla del Pino dirigía en Sab Roque) el tema del Significado del Silencio ${ }^{3}$. Esa aportación supuso mi conversión definitiva de la semiótica a la retórica. Pues habiendo intentado durante dos semanas desarrollar el texto de aquella conferencia desde un punto de vista semiótico, se me reveló ese camino tan inaccesible a la esencia de un fenómeno como el silencio, que tuve que encomendar el primer manuscrito al cesto de los papeles, redactando el texto definitivo desde una perspectiva diferente: la perspectiva retórica. La presente disertación es una continuación a aquel ensayo sobre el Silencio, elaborado cuatro años más tarde, pero hasta ahora inédito.

\section{El ejemplo y la oblicua transparencia del lenguaje}

Quisiera exhortar al lector a adoptar una actitud irónica al dar lectura a mi discurso sobre la ironía. No identifico empero la ironía, como frecuentemente se hace, con el distanciamiento, sino más bien con la oblicuidad. «Da doble luz a tu verso, para leído de frente y al sesgo», decía también Machado. Lee y escucha siempre al sesgo si quieres entender, diría yo. Lee un texto y escucha una disertación no sólo atendiendo a lo que el autor dice, sino también a lo que el autor hace al decirlo. «Cuando se ha llegado tan lejos en sinsentido como yo lo he hecho - decía Gunnar Ekelöf ${ }^{4}$-, cualquier palabra resulta de nuevo interesante». Y cuando hemos aprendido, como yo mismo he hecho, a sacar provecho incluso de textos mediocres y de conferencias aburridas o de poca calidad, estamos en buen camino de alcanzar el verdadero entendimiento. Gadamer sostiene, por su parte, que «a veces el investigador puede aprender más del libro de un aficionado que de los libros de otros inves-

${ }^{2}$ Søren A. Kierkegaard, Om Begrebet Ironi («Samlede værker» B. 1) [Theses, dissertationi danicæ de notione ironiæ, annexæ quas ad jura magistri artium in Universitate Hafniensi rite obtinenda, die XXIX Septemb. hora 10, publico colloquio defendere conabitur. Severinus Aabye Kierkegaard, theol. cand. MDCCCXLI»] 3. udgave, Gyldendal, København, 1982. (1. udgave 1906).

${ }^{3}$ Véase El silencio, comp. de Carlos Castilla del Pino, Alianza Universidad, 1992.

${ }^{4}$ Ekelöf, Gunnar Dikter. Bonniers, Stockholm, 1965. 
tigadores». No siempre son más valiosos los textos o los autores más comentados; conviene buscar el tesoro oculto bajo el polvo y el olvido de las bibliotecas o de los archivos.

La actitud irónica supone el tomar cada acontecimiento como un ejemplo. Y el ejemplo, me enseñó Aristóteles, es en retórica lo que la inducción es en lógica. Lo importante del ejemplo —y cada elocución concreta no es más que un ejemplo- no es tanto lo que dice como lo que muestra.

La enseñanza transmitida por un ejemplo no depende de su bondad, pues también el mal ejemplo muestra y enseña. La maldad advertida, cuando transciende ciertos límites, nos impulsa a reflexionar y a hacernos mejores, hasta el punto de que, a veces, sólo la nequicia es capaz de sacudir nuestra indiferencia y comodidad. Tiene que llegar la sangre al río para que la gente comience a rasgarse las vestiduras y a manifestarse. Las mayores perversidades suelen conducir a las mayores tomas de conciencia sobre lo vitando.

También los errores descubren, pues, caminos. Mi intento - acertado o descabellado - de descifrar y entender lo que significa la ironía, quizá provoque a un lector atento y reflexivo a hacerlo mejor que yo. Pues un texto o una conferencia no debe hablar meramente para la memoria, sino sobre todo para el entendimiento. Mi intención aquí no es enseñar al lector lo que sé, sino describirle el camino recorrido por mí, estimulándole a que emprenda su propio viaje y a que se forme su propio criterio durante el recorrido. Tal es la esencia del diálogo, palabra que no significa simplemente «conversación». Pues ni el prefijo griego dia significa «dos», ni es posible concebir al «logos» — prefijos a un lado- sin un interlocutor real o ficticio. Diálogo es llegar a algo dia logos, «a través del logos», a través del decir. O sea, sin quedarse en lo escuetamente dicho, al contrario trascendiéndolo. La ironía tiene así en común con el diálogo esa oblicua transparencia que da más valor al hacer del decir que a lo dicho mismo.

El punto de partida para entender algo son los ejemplos a través de los cuales ese algo se manifiesta. Para tratar de entender lo que es la prudencia o la virtud moral, Aristóteles no nos remite a su definición, sino a la indagación de los ejemplos vivos de hombres prudentes y virtuosos. "Nada hay en el entendimiento que antes no se halle en el sentido», dice un conocido postulado gnoseológico. Leído al sesgo, ese enunciado dice sencillamente que todo conocimiento universal de algo se alcanza a través de sus manifestaciones o ejemplos concretos. Esto, que suena a puro empirismo, nos enseña que la apariencia no siempre engaña, sino, para una mente atenta, desvela. Pues desvelar es lo mismo que «verdad» (alezeia) en griego. $A$ través de lo que aparece, de lo contingente o fortuito, alcanzamos al meollo o sentido de las cosas. Un realismo que toma totalmente en serio las cosas mismas, es más ilusionista que realista. Pero no faltan los que todavía creen que el dinero son las monedas que llevamos en el bolsillo. Y ¿para qué preocuparse del valor de la moneda? ¿No dice acaso su cuño, o el texto impreso en el billete de banco, cuál es 
su valor? «Todo necio confunde valor y precio», decía Machado. También la devaluación de la moneda es pura ironía.

Si el ejemplo, concepto hoy vacío y desgastado por el uso cotidiano, en realidad representa el eje de todo conocimiento humano, la ironía es el gozne que articula ese conocimiento con el ser mismo del hombre. La ironía es el eje de lo antropológico, ya que, siendo la fuente de todo sentido figurado y de todo tropo retórico, puede decirse que toda antropología incluye y presupone una tropología y que el tercer libro de la retórica aristotélica, que en apariencia se ocupaba de la elocuencia en el discurso, hace relación a la condición general del ser humano en el mundo, en su doble vertiente de existencia y conocimiento.

Ahora bien, hay dos maneras de preguntarse por aquello que se oculta bajo la realidad inmediata, es decir, bajo la apariencia. Ante algo que se nos hace presente cabe preguntar: ¿Qué es esto?, pero también: ¿Qué significa esto? La pregunta por el ser es una pregunta acerca de la realidad, mientras que la pregunta por el significado nos recuerda más bien la interpretación de un texto. Para quien sostiene que toda realidad se asemeja a un texto, la pregunta positiva acerca del ser carece de sentido directo, ya que todo sentido ha de ser interpretado. Esto plantea arduos problemas acerca de la relación entre ser y sentido y entre sentido y significado. Aun sin ser un seguidor de la semiótica, me hallo también en la línea de los que buscan el sentido de la realidad en la interpretación de aquello que se presenta como su significante. Para evitar confusiones explicaré que considero a la semiótica no como una teoría del sentido, sino como una teoría positivista y materialista del significado, diametralmente opuesta a la retórica y a la hermenéutica. Umberto Eco no me va. Y, aun cuando la estructura saussureana del signo ha sido para mí un punto importante de partida, tampoco soy un seguidor del estructuralismo lingüístico, sino más bien de una filosofía del lenguaje, «por supuesto, no en sentido wittgensteiniano», sino en el de Fritz Mauthner (del que Wittgenstein abjura), pero sobre todo humboldtiana y viquiana. Me apunto también a una hermenéutica de origen, como los buenos vinos, no a esa hermenéutica surgida de la decepción de toda filosofía analítica, que nunca logra liberarse del todo de su «aire de familia».

Hago esta división de campos porque considero que el entendimiento del fenómeno irónico depende del camino que se elija. Considero importante evitar la confusión habitual de la ironía con su mera manifestación o expresión. Me explico.

Se llama ironía, en ciertas ocasiones, a ese fenómeno que consiste en decir algo para insinuar o expresar algo distinto e incluso, si bien no siempre, totalmente contrario. Otras veces se denomina ironía la incongruencia entre una intención y un resultado, o el desencaje entre un efecto y aquello que racional o moralmente cabía esperar. El primer tipo de ironía mencionado lo recoge la retórica, el segundo la tragedia. Pues bien, esas cosas, esos hechos y dichos, siendo expresiones de la ironía, síntomas de que algo como la ironía existe, 
no son la ironía misma; a no ser que el propio término «ironía» sea metonímicamente desviado en su sentido, ironizando así con la propia ironía.

Para comprender lo que es la ironía es preciso descubrir lo que revelan ese fenómeno de desviación del sentido literal o esa aparente falta de lógica y consecuencia, captando lo que se oculta tras el fenómeno y lo explica. Se trata de entender, a través de lo que esos ejemplos o fenómenos específicos significan, no ya lo que la ironía produce (su ergon), sino lo que la ironía misma es (su energeia). La respuesta al Qué significa y al Qué es a secas no nos ayudan, sin embargo, suficientemente a explicar y a distinguir, ya que esas dos preguntas están también irónicamente viciadas por sendas ambigüedades.

«Ser» puede entenderse como sustantivo o como verbo, de ahí que unas veces tenga el significado de sustancia y otras el de actividad. Para el filósofo realista, que identifica la metafísica con la ontología, la ironía es concebida como algo realmente sustancial y gramaticalmente sustantivo, aun cuando ese insinuar o decir ocultando, en que ese algo de la ironía consiste, son propiamente acciones. A lo sumo se concibe la ironía como kinesis, un hacer que viene explicado por el resultado al que conduce (su ergon u obra), no como energeia, que es un actuar u obrar constitutivo en sí de sentido. La ironía se concibe así como un algo objetivo que hacemos con las palabras, un resultado del acto de habla. Heidegger fue quizá el filósofo más consciente de este problema y de la condición de la ironía como categoría existencial humana, aunque - como Jean Wahl parece haber visto ${ }^{5}$ - no logró liberarse del prejuicio ontológico. Por eso quedó inacabada su obra sobre El Ser y el Tiempo. Tomando el rábano por las hojas, la ontología confunde el SER con su huella.

A diferencia del ser, alude el «significar» a una relación según la cual una cosa remite a otra diferente, a la cual representa ${ }^{6}$. Lo que se expresa o muestra (el significante) remite a un significado tácito. La concepción del signo se aproxima así, de una manera inquietante, a la concepción usual de ironía. ¿Es que acaso el signo y la ironía son una misma cosa? Por ahí van los tiros. Volveremos sobre esta cuestión. Quiero, no obstante, prevenirles de la existencia de una concepción del significado que prácticamente no difiere de la ontología. Preguntarse «qué significa la ironía» lleva a menudo (como ocurría con la pregunta por el significado del silencio), a una confusión entre lenguaje objetivo y metalenguaje. Decir que la ironía es «dar a entender lo contrario o algo distinto de lo que se dice» no es desvelar el significado de la ironía, sino simplemente el de la palabra «ironía». El significado de las palabras se establece en los diccionarios sustituyendo un significante por otro nuevo de palabras diferentes, las cuales exigen nuevos significados, expresados en nuevas palabras

${ }^{5}$ Jean Wahl, Vers la fin de l'ontologie. Étude sur l'introduction dans la métaphysique par Heidegger, Société d'Édition de l'Enseignement Supérieur, Paris, 1956.

${ }^{6} \mathrm{El}$ ejemplo, al que he aludido antes (pág. V), se comporta así también como una especie de significante al servir de medio para el conocimiento de otra cosa. 
significantes, y así hasta el infinito. Decir que «jabalí» significa «cerdo salvaje» tiene sólo sentido para el que, no sabiendo lo que es un jabalí, sabe, en cambio, lo qué significa «cerdo» y «salvaje». Según esto, saber algo nuevo exigiría saber de antemano algo de mayor extensión y menor contenido. Todo aprendizaje a partir de cero se haría así imposible, exigiendo siempre un saber previo y negando toda experiencia capaz de crear conocimiento sin conceptos innatos. Las teorías lingüísticas del significado quedan encerradas en una regresión infinita, sin jamás poder apresar significado, último alguno, ya que todo significado expresado no es ya un significado sino un nuevo significante. El significado se esconde, pues, cuando tratamos de apresarlo, dando lugar a eso que Lacan llamaba el deseo metonímico.

\section{La ironía y el escándalo del lenguaje}

La ontología es una semiótica disimulada y viceversa. Tanto el ontologismo como el semioticismo confunden la ironía con los hechos y situaciones específicos a los que se da el nombre de ironía, lo cual es una petición de principio, dejando intacto el ser de la ironía misma. Cuando yo me pregunto qué es la ironía o qué significa la ironía, lo que busco es justamente el sentido explicativo de esos hechos y esas situaciones, la respuesta a icómo es posible decir lo diferente de lo que se dice?, o a iqué revela el hecho de que alguien diga algo para dar a entender lo contrario o lo distinto?

De un acto de perplejidad (zaumadsein) surge, según Aristóteles, toda pregunta auténtica y radical. Mi pregunta acerca de la ironía es provocada por la perplejidad que me produce el hecho de que algo pueda significar una cosa distinta de lo que literalmente dice, cosa que, a todas vistas, es una flagrante contradicción y debería suponer una imposibilidad. La pregunta sobre la ironía (otra ironía de la ironía, pues toda pregunta es irónica por esencia) se alza, pues, sobre un escándalo, que es el escándalo del conocimiento y del lenguaje humano. El mejor intérprete de ese escándalo es quizá Nietzsche, pero ya Vico había anticipado una concepción del lenguaje en esa misma dirección.

Posteriormente a Vico y Nietzsche, seguirán planteando el problema como escándalo tanto Kierkegaard como Wittgenstein, para quedar al final malabaristamente tergiversado en las teorías del significado al uso, incluida en parte la del propio Wittgenstein. Si el lenguaje es un sistema de significantes y lo esencial de todo significante es remitir a algo distinto de él, sin que le una a ello ninguna necesidad causal, sino la mera conexión realizada por una mente, la ironía será algo subyacente a la esencia misma del lenguaje. Pero las teorías de la significación posteriores a Saussure, disimulan el abismo sobre el que se alzan, a base de interpretar la significación según el viejo modelo de la verdad como correspondencia. De poco sirve a este respecto que aludan a la llamada arbitrariedad del signo (teoría también torcida, porque se basa en una verdad a medias) o que hayan advertido, a su manera, el fenómeno de 
la polisemia y las desviaciones de sentido; pues al considerar este fenómeno como algo accidental en el uso lingüístico, dejan de ver, como lo vio Nietzsche, que la polisemia y la desviación del sentido caracterizan al lenguaje como tal y no sólo a ciertas expresiones de él. El lenguaje se comporta como la superficie del agua, que al ser atravesada por un rayo luminoso, lo refracta y desvía.

$\mathrm{Ni}$ existe, pues, paralelismo o correspondencia directa entre lenguaje y sentido, como supone la lingüística, ni tampoco la arbitrariedad del lenguaje es total, como ella cree. Los signos del lenguaje son arbitrarios sólo hasta cierto punto, pues aunque pueden recibir significados diferentes sin perder su inteligibilidad, no por eso admiten cualquier significado. Aunque las elija e incluso las cree libremente, nadie usa o inventa palabras sin un motivo y sin tener en cuenta usos establecidos, no meramente convenidos. Entendemos por mediación del significante, pero no gracias a él. Si un león pudiera hablar - decía Wittgenstein - no lo entenderíamos. El hecho de que los seres humanos podamos entendernos unos con otros a través del lenguaje (dia-logos), está basado en algo que trasciende al lenguaje mismo y que posibilita su uso como instrumento. Podemos entender el lenguaje porque lo hemos hecho nosotros, siguiendo la teoría viquiana del factum verum. Pero también es cierto que unas mismas palabras pueden entenderse de maneras diferentes y que un mismo significado puede usar expresiones dispares. El lenguaje aparece como un vidrio ventanal, a través del cual (dia-logos) damos expresión al sentido.

\section{Ironía, retórica y gestación lingüística}

Los tratados de Retórica, esa retórica mutilada e instrumental que nuestro siglo heredó, han tratado de encerrar los problemas de la polisemia y la desviación de sentido en un apartado especial que es la teoría de los tropos. ¡Cómo si esas desviaciones afectaran sólo a ciertos usos del lenguaje! En su prolija clasificación de desviaciones semánticas y su inacabable lista de recursos estilísticos, la retórica trata a la ironía como un tropo particular cualquiera, caracterizándola escuetamente como un «decir algo expresando lo contrario», lo cual supone una notable reducción. Por si era poco suele añadir que el sentido de lo dicho irónicamente se desprende de los gestos que lo acompañan o de otras huellas o conocimientos previos del oyente, que le ayudan a no interpretar lo dicho en sentido literal. Con lo cual el sentido de la ironía desaparece. Tratar de deshacer la paradoja de la ironía es tan vano como intentar dar expresión a un significado formulando nuevos significantes. La ironía, como el sentido, se esconde siempre detrás de lo que mostramos, siendo lo mostrado su mero ejemplo y su significante.

$\mathrm{Al}$ incluirla entre los tropos, los manuales de retórica hacen una separación virtual entre la ironía y las demás figuras de dicción, como la metáfora y la metonimia. Pero lo que en realidad se hace es dar el nombre de ironía a 
algo que ya no lo es propiamente. Confinada en una camisa de fuerza estilística se resiste la ironía a dejarse encerrar en un solo término de la expresión. Mientras las restantes figuras retóricas constan en principio de una sola palabra o de una expresión que sólo es parte de un enunciado, se manifiesta la ironía en enunciados completos y a veces en un complejo de varios enunciados. Por eso hay dudas entre los retóricos acerca de su supuesto carácter de figura, queriendo algunos convertirla en figura de pensamiento, más que de dicción. La reducción de la ironía a tropo o figura es, en realidad, el resultado de una metonimia seguida de una sinécdoque: primero se la identifica con su mera expresión lingüística (con su ejemplificación) y acto seguido se la reduce a sólo una parte de lo que esa expresión abarca.

$\mathrm{Al}$ hacer de la ironía un tropo específico, los manuales de retórica son, como los recetarios de cocina, incapaces de sustituir a la experiencia de un buen cocinero. La Retórica, como la Política, considerada como mera técnica, promete más que cumple. Para poder jugar al ajedrez hay que aprender sus reglas antes de practicarlas, pero para argumentar o hablar bien hay que tener ya una práctica adquirida antes de estudiar las reglas de la lógica o la retórica. La retórica como recetario sólo puede ser útil para el perfeccionamiento del que ya domina bien el discurso y la argumentación. Bueno es que seamos conscientes de nuestros actos, pero una conciencia exagerada supone más bien una traba que una ventaja del arte. Sólo cuando, una vez aprendido y asimilado, sin dejar de saber lo que hacemos, dejamos de pensar en cómo lo hacemos para simplemente hacerlo, podemos considerarnos maestros en una técnica o actividad.

El propio uso cotidiano de la palabra «ironía», no digamos ya de su etimología, desborda y contradice el concepto instrumental de la ironía como figura retórica. Pues decimos hacer uso de la ironía, no sólo cuando expresamos lo contrario de lo que significamos, sino sencillamente cuando desviamos expresivamente el sentido de lo que decimos, por inseguridad, modestia, reticencia u otros motivos. Llamamos además ironías a situaciones trágicas y cómicas en las que el principio y el final, la premisa y la conclusión son incongruentes con lo que la lógica, la justicia o el sentido común harían esperar. El valor atribuido a la tragedia clásica reside en su capacidad reveladora de la ironía como condición existencial humana.

Todo uso de la ironía como recurso o triquiñuela, toda instrumentalización de lo irónico, aunque conserve su aire familiar, tiende a alejarnos de su auténtico sentido. Hacemos conscientemente uso de la ironía con malicia o bondad. Malignamente en la invectiva, el comentario mordaz, la sátira. Benignamente en el humor. Pero el uso consciente y oportunista la desvirtúa, al convertirla en mero instrumento arbitrario. La ironía auténtica es una constante tensión, un flujo reiterado que nutre la fantasía, abona la invención y mantiene vivo el hilo del discurso y de la acción, sin apenas darnos cuenta de ello, en esa 
antesala de lo consciente que Freud llamaba preconsciente o inconsciente descriptivo (latente), por oposición al inconsciente dinámico, límite de lo reprimido ${ }^{7}$.

En su magnífico libro sobre El Gran Humor ${ }^{8}$, explica el filósofo danés Harald Höffding que la diferencia entre ironía y humor es que mientras la ironía expresa lo cómico mediante lo serio, el humor expresa lo serio mediante lo cómico. Pero ambas son expresiones de una ironía que Höffding llama «la gran ironía», a diferencia de la pequeña, de modo semejante a como yo distingo entre la expresión de la ironía y la ironía en sí, como categoría existencial humana.

El uso corriente confunde, dije, la ironía con su resultado. Una cosa es la ironía y otra son los ejemplos en los que ésta se hace patente. Una aproximación a la ironía como aquello que fundamenta y trasciende sus ejemplos, nos lleva a una concepción socrática de ella, acorde con la propia etimología de la palabra «ironía». La eironeia socrática arraiga en esa condición humana que nos otorga conciencia de que, en el fondo, nada podemos saber ni expresar con adecuación plena. Entre el absoluto no saber y el creer saber, aparece la ironía como una tensión que da origen al modo lingüístico de la interrogación. La interrogación es ignorancia a sabiendas, ya que todo el que interroga ignora y sabe, al mismo tiempo, algo. Tanto Collingwood como Gadamer ${ }^{9}$ han visto en el preguntar, que es la expresión primera de la ironía, la fuente de la lógica y del discurso. No hay enunciado, ni siquiera científico, que sea del todo verdadero, sino que cada enunciado es una respuesta a una pregunta motivada y tácita. La ciencia es un sistema de respuestas a preguntas tácitas cuyo resultado no es un saber, sino una pretensión de saber y un intento de decir de clara raigambre irónica. Mas la ironía no es la propia pregunta, sino aquella condición del individuo humano cuya manifestación lingüística más propia es la pregunta.

La ironía no se deja definir, siendo más bien ella la que promueve los intentos de definición, dando coherencia a todos los recursos lingüísticos y a todas las figuras retóricas, que también son recursos lingüísticos. Podemos caracterizar la ironía, pero no definirla. En su tesis doctoral sobre la ironía la interpretaba Kierkegaard como una forma de negatividad. Solamente en su obra madura llegó el filósofo danés a comprender el valor positivo auténtico de la ironía. El rasgo distintivo de la ironía más comúnmente aceptado quizá sea el distanciamiento, pero, a mi juicio, también éste es vacilante, puesto que la ironía no sólo distancia, sino que, al propio tiempo, como toda tensión, aproxima y sujeta. La ironía supone la facultad humana de merodear la realidad sensible asentando en ella el nido del sentido. Se trata de un merodear dis-

\footnotetext{
${ }^{7}$ Sigmund Freud, El yo y el ello y otros escritos de metapsicología, trad. de Rey Ardid y López-Ballesteros, Alianza Editorial, 1973, pp. 8 y ss.

${ }^{8}$ Harald Høffding, Den store Humor, Gyldendals, København, 1967.

9 R. G. Collingwood, Autobiografía, y trad. de Jorge Hernández Campos, México, FCE, 1953, y Hans-Georg Gadamer, «Verdad y método II», trad. de Manuel Olasagasti, Sígueme, 1992.
} 
cursivo, pues mientras Dios sólo necesita de la intuición, siendo un Acto Puro que todo lo entiende en su propia idea, es condición de un dios a medias como el hombre, el verse sometido al rodeo del discurso y de los signos para hilar el sentido de su mundo y entenderlo. Ese rodeo obligado del discurso en torno al sentido representa a la ironía. La posición existencial del hombre, intermedia entre el dios y la bestia, se debe a que, siendo cuerpo vivo, sin embargo no es sólo cuerpo. La zoé no conoce ironías, las ironías de la vida son siempre ironías de la bios.

$\mathrm{Al}$ psicoanálisis y a la psicolingüística se debe en gran parte la superación de la doctrina retórica de las figuras, presa en sus condicionamientos instrumentales, restringidamente expresivos y literarios. Giambatista Vico que, 200 años antes de Nietzsche, era ya consciente del valor de la retórica como saber antropológico por excelencia, había reducido la lista de las figuras o tropos a cuatro: la metáfora, la metonimia, la sinécdoque y la ironía. César Dumarsais, en su tratado sobre los tropos de 1793, había hecho notar que las figuras de dicción no sólo aparecen en el discurso premeditado de la oratoria y la literatura, sino que están presentes en todo uso espontáneo del lenguaje. En un solo día de mercado en París decía Dumarsais haber advertido más metáforas que en toda la literatura francesa.

La psicolingüística moderna viene a establecer lo que ya Nietzsche sabía, que las estructuras retóricas y la teoría de las figuras no son meros instrumentos de la elocuencia ni mera habilidad de agudos e ingeniosos, sino mecanismo necesario de todo hablar, de la formación misma de los conceptos y de la estructuración normal del discurso. El esquema viquiano de cuatro figuras ha quedado para Roman Jakobson reducido a dos: metáfora y metonimia. Intuye Jakobson el carácter psicolingüístico profundo de éstas, rastreando sus huellas en los desajustes articulatorios de los afásicos, mediante experimentos bien conocidos ${ }^{10}$. Jacques Lacan, por su parte, identificando la encrucijada de la condensación y el desplazamiento, en la interpretación freudiana de los sueños, como expresión metafórica y metonímica respectivamente, utilizará los dos viejos tropos retóricos en la elaboración de una metapsicología en la que el inconsciente se considera estructurado como un lenguaje ${ }^{11}$.

Sin estar en deuda directa con ellos (deudas indirectas tengo, a veces sin saberlo, con muchos), me ha cabido la satisfacción de ver que mis conclusiones sobre la retórica y sus figuras concuerdan bien, aun sin coincidir en detalle, con lo que Lacan y sobre todo Nietzsche sostienen. Al estar redactando este texto llegó a mis manos el libro de Enrique Lynch Dioniso dormido sobre un

${ }^{10}$ Roman Jakobson, Dos aspectos del lenguaje y dos tipos de trastornos afásicos, en R. Jakobson y Morris Halle, Fundamentos del lenguaje, trad. de Carlos Piera, 2. ${ }^{a}$ ed., Editorial Ayuso, 1973 (la primera edición en Ciencia Nueva, 1967).

${ }^{11}$ Jacques Lacan, El Seminario, Libro 3: «Las psicosis, 1955-1956», Barcelona, Paidós, 1984. Rifflet-Lemaire Anika Lacan, con pról. de Jacques Lacan, trad. de Francisco J. Millet, Sudamericana, Buenos Aires, 1976. 
tigre $^{12}$, sobre la teoría del lenguaje de Nietzsche, que inesperadamente aporta apoyo y fundamento a mi exposición. Reduciendo el esquema viquiano de los tropos a dos: metáfora y metonimia, que incluye a la sinécdoque dentro de la metonimia, como una variante suya, queda la ironía totalmente fuera del esquema. Lo cual supone un progreso, pues su alineamiento entre las figuras de dicción sólo contribuía al torcido entendimiento de su carácter.

Siendo la ironía para mí una categoría existencial, la metáfora y la metonimia representan el instrumento mental a su servicio. Por debajo de los usos lingüísticos concretos, la metáfora y la metonimia constituyen dos coordenadas mentales integrantes de un mecanismo psicofísico mediante el cual se manifiesta y opera la ironía. Permítaseme considerar más detenidamente su uso lingüístico, antes de bucear en las entrañas del fenómeno de los tropos y de la ironía.

\section{Desplazamientos metonímicos}

Se cuenta que Napoleón, dirigiéndose a sus soldados, alineados al pie de las pirámides de Egipto, dijo: «Soldados: desde lo alto de estas pirámides cuarenta siglos os contemplan.»

Cabe preguntarse a santo de qué hacía el general francés esa extraña afirmación. Si nos atenemos literalmente a lo que las palabras dicen, nos encontramos con algo tan disparatado como pretender que los siglos transcurridos, cual si de personas humanas se tratara, poseen ojos y, habiéndose encaramado en la cúspide de las pirámides de Egipto, se dedicaban a la dudosa diversión de observar a las tropas de Napoleón.

Si el lenguaje figurado, como pretende una retórica de orfebrería, no es más que la dicción elegante de algo que podría decirse en sentido directo, entonces bastaría con traducir la perorata napoleónica a ese lenguaje directo: «Soldados, estas pirámides, bajo las cuales os encontráis, tienen cuarenta siglos de antigüedad.» La frase napoleónica se convierte así en un enunciado informativo, propio de un guía turístico moderno. Pero la intención del caudillo galo era, sin duda, otra. Napoleón, de cuya afición al turismo cabe dudar, estaba arengando a sus soldados para estimular su espíritu de valentía, no para contarles historias.

Sin necesidad de seguir las recetas retóricas, Napoleón sabía por instinto social lo que es usar metonimias en el discurso. Los siglos que según él contemplaban a sus soldados, representaban a las generaciones pasadas, que tantos hechos habían presenciado y tanta experiencia habían acumulado. Su paso por aquel lugar histórico exigía del ejército francés un alarde de sus mejores dotes guerreras. Napoleón sabía que es más fácil despertar un sentimiento

\footnotetext{
${ }^{12}$ Subtítulo: A través de Nietzsche y su teoría del lenguaje, Destino, 1993. Años después de redactado este texto ha aparecido: Friedrich Nietzsche, Escritos sobre retórica, Trotta, 2000, excelentemente traducido y comentado por Luis Enrique de Santiago Guervós.
} 
en lenguaje indirecto que dando órdenes. Decir: «Te vas a quemar» es más efectivo para hacer a un niño que deje de acercarse a un fogón que ordenarle «No te acerques aquí».

$\mathrm{Si}$, dejando a un lado situaciones intencionadamente solemnes como la de la anécdota napoleónica, en las que se trata de «hacer cosas con las palabras» más que de decir algo, observamos otros usos lingüísticos más corrientes, cotidianos u oficiales, que parecen pretender decir algo informativo de un modo directo, advertimos que tampoco en esos casos puede el lenguaje evitar los usos metafóricos o metonímicos. Lo mismo que un significante al tratar de descifrar su significado sólo produce nuevos significantes, al tratar de explicar expresiones metafóricas y metonímicas en lenguaje llamado directo, cometemos nuevas metáforas y nuevas metonimias aún más sutiles. Cuando yo hace un momento trataba de redecir la frase napoleónica en sentido directo, lo único que hice fue usar nuevas palabras de sentido oblicuo menos patente que las anteriores. «Encontrarse» bajo las pirámides «tener años» y «años de antigüedad», ¿qué es esto sino hablar indirectamente?

El español diario, quizá en mayor medida que otras lenguas europeas, es riquísimo en usos lingüísticos metonímicos. La expresión «Encender la luz», por ejemplo, es un desvío semántico común a muchos idiomas. «Tirar de la cadena», en lugar de «enjuagar», refiriéndose a ese recipiente de nombre tabú al que también metonímicamente llamamos «retrete», es una denominación cada vez más obsoleta para la que el español no ha elaborado un sustituto. Nuestra lengua es extrema en usos desviados innecesarios y hasta cómicos. A la salida de escuelas con mucho tráfico rodado, por ejemplo, figura un letrero que dice: «Peligro, escolares». Y no deja de resultar sorprendente para el usuario telefónico no hispano que marca por equivocación un número carente de abonado, el escuchar en el auricular una voz rotunda que dice: «iEl número que usted ha marcado, no existe!». Ejemplos como éstos son tan divertidos como inocuos. Más peliagudo es, en cambio, el uso kantianizante español de «poder», en lugar de «deber». No hace mucho, al intentar entrar en un edificio público de interés artístico, me salió al paso un ordenanza diciendo: «iNo se puede entrar!». Me limité a demostrarle que sí se podía, entrando. Usos lingüísticos de esta índole pueden ser síntomas de una mentalidad y un orden social algo perversos. Como los lapsos lingüísticos en el psicoanálisis, esos usos muestran y dicen más de los hablantes (como individuos o como grupo social) que de aquello de lo que se pretende hablar.

El sentido indirecto tiene, pues, tres fundamentos:

1. El uso intencional consciente,

2. La costumbre arraigada e inconsciente, $y$

3. La necesidad lingüística.

La retórica de manuales sólo se ocupa del primer tipo, el uso consciente. La ciencia moderna del lenguaje ha comenzado a ocuparse del segundo, el uso inconsciente. La antropología, tal y como yo la entiendo, penetra en el 
tercer tipo. Éste es el nivel profundo de la ironía, cuyas obreras son la metáfora y la metonimia.

\section{Metáfora y metonimia, obreras del sentido al servicio de la ironía}

Me he venido refiriendo a metáforas y metonimias inconscientes, tan evitables como, a veces, vitandas. Pero la metáfora y la metonimia en general son inevitables para cualquier uso lingüístico. Detrás de todo acto de habla se ocultan, como en la tramoya de un escenario, esos dos elementos estructurantes del sentido del discurso. La formación de enunciados, la creación de nuevos conceptos e incluso nuestra forma de ver (noten que digo «ver») la realidad, están sometidas a una incesante y coordinada tarea metafórica y metonímica. Al hablar de «visión de la realidad», estamos diciendo, sin darnos cuenta, que la realidad es algo que se ve, a diferencia de lo que se oye. Ésta y otras muchas observaciones de los usos lingüísticos desenmascaran la prioridad que un hablante occidental otorga, sin advertirlo, al sentido de la vista complementado por el tacto. Lo auditivo es reducido a lo visual y la lengua escrita se convierte en norma de la lengua hablada. Metafórica y metonímicamente creamos conceptos nuevos a partir de otros viejos y conceptos abstractos a base de objetos materiales. Nótese que he dicho «concepto», palabra procedente del latín «capio» (a-garrar), y lo califico de «material» (que originariamente significa «de madera»).

La «visión» occidental de la realidad y su pensamiento científico están determinados por el paradigma del espacio y de la geometría. El famoso pórtico de la Academia de Platón sigue simbolizando la entrada al mundo de la cultura europea, cuyos vástagos son la tecnología, la ingeniería social del Estado del Bienestar y la moderna economía política, reemplazadora en la sociedad moderna de la función que en la antigua desempeñaba la teología. La transición metonímica (no sólo metafórica como Nietzsche cree) de «los hombres»a «el hombre», transitando de una forma plural a una falsa forma de singular que es mera abstracción de la pluralidad, nos conduce a ese «hombre» de la estadística que es al mismo tiempo todos y ninguno. Ser europeo es ser fanático de la identidad y angustiado de la diferencia. Eso es el etnocentrismo.

Pensar es pesar. Lo corporal determina lo conceptual y la metonimia no sólo actúa a nivel semántico, sino también a nivel categorial, lo cual pocos, entre ellos Nietzsche, han advertido ${ }^{13}$. Concebimos fuerzas y acciones reificándolas y sustantivándolas. Explicamos las acciones por las cosas o por las personas corpóreas, interpretando la fuerza y la actividad desde su sujeto o desde su objeto, cuando lo fenomenológicamente adecuado sería explicar las

\footnotetext{
${ }^{13}$ Nietzsche parece, sin embargo, caer en la trampa occidental gnoseológica (que, por otro lado quiere combatir) de la metáfora y la identidad, sin que parezca tener suficientemente clara la función de la diferencia y la metonimia.
} 
cosas y las personas (que son la apariencia, el signo) por las acciones, las fuerzas o las operaciones que las crean y les dan sentido ${ }^{14}$. Los antiguos convertían metonímicamente actividades y cualidades abstractas en personas míticas. En el Olimpo habitaban el Amor, la Justicia, la Guerra, el Comercio... Nuestro fingido monoteísmo, no sólo no ha desterrado a los viejos dioses, sino que ha aumentado su número. El Socialismo ha sido sustituido por su antagonista, el Mercado. La Crisis Económica es la culpable de nuestros males nacionales, sin que surja un Edipo que resuelva el enigma de la Esfinge. La Inflación y el Paro son dragones ante los que nuestros héroes nacionales se hallan impotentes. El Desarrollo es un santo de universal veneración. Y todos adoran en su fuero interno, criticándolo en lo público, a ese tal Enrique Cimiento. Dicen que la Peseta está amenazada, ila pobre! Desaparecido el latín de la liturgia eclesiástica, los teólogos de la sociedad del bienestar, expertos en Ciencias Económicas, llevan años invadiendo el espacio social de la comunicación con una jerga ritual que, como todos los ritos, es tan conocida y usual como ininteligible. A pesar de la afición de los españoles al juego de palabras, no sé quien juega más si ellos con las palabras o las palabras con ellos.

Pero la desviación del sentido no es siempre, repito, una perversión eludible, sino un elemento constitutivo del habla y, por ello, inevitable. Adviértase cómo en nuestros enunciados manejamos el sujeto gramatical como si fuera un agente responsable: decimos que «El poder corrompe», que «El Sida hace estragos», que «La polución envenena a las ciudades» y que «Los precios han subido». Reificamos las acciones y personificamos las cosas y los hechos. No para eximirnos de nuestra responsabilidad, aunque la verdad es que el efecto es el mismo, pues mientras sea «el poder» el que corrompe, el poderoso es más bien una víctima. El mismo fenómeno se da, sin embargo, en situaciones tan poco sospechosas de intencionalidad o malicia, como, por ejemplo: «El curso ha comenzado», «Se fue la luz», «El coche no quiere arrancar» $\mathrm{o}$ «La fuente se ha secado y las azucenas están marchitas en el camino verde que va a la ermita», como decía la vieja canción.

Todo lenguaje humano, sea a nivel semántico inmediato o a nivel histórico y etimológico, se cincela en el taller de la metáfora y la metonimia. Podemos, a lo sumo, ser conscientes de este hecho, pero jamás eludirlo. Suprimir la metáfora y la metonimia sería suprimir el lenguaje. Sin embargo, siendo éstas condición necesaria del lenguaje, no son condición suficiente. Sin la presencia del sentido articulado por ellas, reducimos el lenguaje a un mero sistema de signos formales como la matemática, en la cual buscan su modelo la ontología y la semiótica. Mas como el ser humano es inseparable del lenguaje (pues o se comunica lingüísticamente o no es humano) y hablar o comunicarse es

\footnotetext{
${ }^{14}$ Tanto para el cartesianismo como para la fenomenología husserliana lo auténticamente inmediato e indubitable es el acto de pensar, siendo tanto el sujeto, para el uno, como el objeto, para los otros, elementos derivados de ese pensar.
} 
dejar al sentido expresarse, tiene necesariamente que hacerlo indirectamente y con rodeos. El hombre es así un animal retórico. Mientras que la razón lógica puede encomendarse a una computadora, que hace su tarea y saca sus conclusiones con más exactitud y rapidez que nosotros, la razón propia e inalienable del hombre es una razón retórica, discursiva. El ritual de los signos semánticamente impregnados, es lo que permite al hombre entender la realidad y dominarla, pero también alienarse, confundiendo los signos que usa con el significado que crea y les atribuye. Toda objetivación es alienación y enmascaramiento. Podemos afirmar que vemos, por ejemplo, buzones de correos, aparcamientos de automóviles, escuelas. Pero «ver» eso es imposible y afirmarlo literalmente es absurdo. Lo único que hacemos es interpretar buzones, aparcamientos o escuelas en las impresiones sensibles que esos objetos o «realidades» nos producen. Para poder ver un buzón de correos hay primero que haber aprendido a verlo, viviendo en una cultura humana que construye y utiliza esos artefactos. Por eso decía Vico que el hombre sólo entiende lo que él ha hecho. Lo demás sólo lo entiende su creador, Dios. Pero cuando vemos los árboles del bosque y los interpretamos en nuestro contexto humano, introducimos lo natural en la cultura. Pues todo conocer humano, es decir, todo conocer, es cultura, interpretación, desviación y manipulación de sentido: ironía.

\section{La raíz biológica de los tropos}

Estoy describiendo la situación original del hombre como ser en el mundo a base, por un lado, de dos coordenadas (metáfora-metonimia) que le ayudan a estructurar el pensamiento y el lenguaje como instrumento para manejar la realidad, preñándola de sentido, y, por otro lado, de una categoría existencial, la ironía, que sustenta y justifica la labor de dichas coordenadas.

En la superficie de la vida lingüística afloran lo que la retórica llama metáforas y metonimias como ejemplos o resultados concretos de actuaciones cuya clasificación ha dado lugar a esos dos conceptos sustantivos. Pero la metáfora y la metonimia no son simplemente un algo, no son palabras, ni sustancias, ni cosas, sino mecanismos psíquicos e incluso psicofísicos, que estructuran los significantes para engarzar en ellos el significado. Los propios nombres de «metáfora» y «metonimia» con que los retóricos — separando a la una de la otra - designan a ciertos recursos expresivos, son metonimias del nombre de una actividad mental en la que cooperan inseparablemente mecanismos metafóricos y metonímicos. Metáfora y metonimia son el reverso del acto mental de la identidad y la diferencia que, de modo elemental, está presente en todo ser biológico. También el animal identifica y diferencia, asocia y disocia a su manera. En el conocido experimento de Pavlov advertimos la raíz biológica del fenómeno metonímico: cuando el perro oye la campana habitualmente anunciadora del alimento se le hace la boca agua. Muchos fenómenos biológicos 
humanos y espontáneos gozan de ese carácter asociativo puramente animal. La proximidad del alimento pone en función las glándulas salivares. Todo macho siente atracción sexual por la hembra al verla o al percibir su cercanía. Metáfora y metonimia son, a nivel biológico elemental, una especie de instinto.

Esa fuerza biológica de mero psiquismo animal se sintetiza y sublima mentalmente en el hombre, otorgando fundamento a la construcción conceptual de la realidad. Lo que entendemos por causalidad (que Nietzsche consideraba una metáfora) es producto del mecanismo metonímico de asociación por contigüidad. Y el paso lógico de las premisas a las conclusiones es una ruta marcada por el instinto o impulso metonímico (que Lacan llama deseo) imitado y utilizado por la mente. En el fondo se trata de mecanismos para sobrevivir y dominar, cimentando lo que para Nietzsche sería la voluntad de poder.

La mecánica de metáfora y metonimia es también el origen de la abstracción, que es una metonimia de lo concreto a lo abstracto y de lo particular a lo universal, acuñándose su determinación o identificación sígnica por obra de la metáfora. Nietzsche ha aludido al elemento metafórico de este proceso, pero no al metonímico. Mientras la metonimia supone el paso de lo uno a lo otro, la metáfora es lo que da nombre a esos elementos sucesivos. La metonimia es como el autobús urbano en marcha, siendo la metáfora el timbre que lo hace detenerse, al propio tiempo que el conductor anuncia el nombre de la parada.

Mucha tinta se ha vertido acerca de la metáfora. Pocos son, en cambio, los libros dedicados a la metonimia. Cosa altamente significativa de nuestra mentalidad occidental, que consagra el altar de su conocimiento al ídolo de la Identidad. Lo que calificamos corrientemente (en terminología retórica) de metáfora es, sin embargo, sólo la obra de la metáfora, su ergon, cuyo mecanismo creador sólo es inteligible en coordinación con la obra de la metonimia. Metáfora y metonimia, como mecanismos — no como efectos sustantivos de ellos - se hallan estrechamente ligados uno al otro, al servicio de la condición existencial humana de la ironía. Consideradas (metonímicamente) como meras figuras retóricas, como productos lingüísticos, la metáfora es más patente y más fácil de identificar que la metonimia, ya que la metáfora supone identificación, pero la metonimia deslice y ocultamiento. La metonimia es, por ello, tanto más enigmática e interesante, incluso a nivel retórico, ya que en ella se basan los deslices más vergonzantes y las manipulaciones del sentido más sibilinas.

La metáfora como tropo o figura se define como una semejanza perceptible entre lo que se nombra y aquello de lo que se toma el nombre. Por ejemplo, cuando decimos que una situación dada es un «lío» o que una persona es «una lumbrera». La metonimia es escurridiza e inaprehensible y se basa en un desplazamiento del nombre de algo a lo que le es contiguo o mantiene relación con ello. Decir «El cabeza de familia» o nombrar a la monarquía como «La corona» son expresiones metonímicas fácilmente identificables; más difícil es 
advertirla en expresiones como «zapatos rebajados» (cuando lo rebajado es el precio de los zapatos, siendo «rebajar», por añadidura, una metáfora) o en la de «acusar a Estados Unidos» (cuando es a sus dirigentes políticos a quien se acusa). Y todavía más inadvertible resulta cuando un hombre público dice «Nosotros» o «El Gobierno» o cuando un ministro sueco de trabajo promete a los trabajadores mayor influencia en la dirección de la empresa, otorgando al Sindicato representación en ella. Mucho se ha hablado del poder de la metáfora, pero muy poco de las metonimias del poder, que son más interesantes, ya que todo ejercicio de poder está basado en desplazamientos sutilísimos del sentido. Todo discurso político está lleno de metonimias que funcionan como la ironía vuelta del revés, otra ironía de la ironía, ya que no tratan de dar a entender lo contrario de lo que dicen, sino de dar a entender justamente lo que dicen, significando algo distinto.

Las gramáticas occidentales están montadas sobre una transposición metonímica de lo auditivo a lo visual y de la acción al sustantivo. Y la ontología, hermana de esa gramática, vive - aunque crea lo contrario- de la reducción de lo espiritual (Geist) a lo material. Según los antropólogos, los indios hopi, expresan que «Un hombre corre» diciendo algo así como «Lo corriente hombrea». Nosotros llamamos «mesas» a las cosas con las que «meseamos», las cosas que hacen de mesas para nosotros. A raíz de las últimas elecciones se leía un letrero sobre una pared madrileña, que decía: «La democracia es corrupción». Me vino a las mientes otra frase que, diciendo literalmente lo contrario, podía, no obstante, conservar el mismo sentido: «La corrupción no es democracia». Ambas frases pueden ser simultáneamente verdaderas y apuntar al mismo mensaje, con la condición de que el concepto de «democracia» se conciba desde dos perspectivas diferentes. En el primer ejemplo se identifica «democracia» con «parlamentarismo», con la actividad reglamentada de la clase política, en el segundo con una ética o forma de comportamiento ciudadano. Los desplazamientos inadvertidos entre la actividad y la estructura de la actividad son fenómeno constante y desempeñan un papel importante en la evolución semántica de la lengua. La palabra latina «civitas», por ejemplo, ha originado la palabra «ciudad» y como tal la traducimos. Sin embargo, como testimonia San Isidoro de Sevilla, «civitas» se refería a la actividad de los ciudadanos, llamándose «urbs» a la fábrica o artefacto material que nosotros llamamos «ciudad», ámbito físico dentro del cual esa vida se desarrolla ${ }^{15}$. Decimos también «camino» pensando unas veces en lo que vemos en el terreno y otras, como en el poema machadiano, en el andar.

Metonímicas son estas alteraciones de perspectiva conceptual, que sin afectar al contenido semántico propiamente dicho, se diferencian sólo en la pers-

\footnotetext{
15 «Civitas (ciudad) es una muchedumbre de personas unidas por vínculos de sociedad, y recibe ese nombre por sus ciudadanos (cives), es decir, por los habitantes mismos de la urbe [porque concentra y encierra la vida de mucha gente]. Con el nombre de urbe (urbs) se designa la fábrica material de la ciudad, en tanto que civitas hace referencia, no a sus piedras, sino a sus habitantes.» (Etymologiarum, XV, 2, trad. española de la Biblioteca de Autores Cristianos).
} 
pectiva desde la que ese contenido se contempla, otorgando prioridad a un aspecto sobre otro. «Ciudad» es para nosotros, en primer lugar, la estructura física, pero también, derivadamente, la actividad humana desplegada dentro de ella. Para los latinoparlantes era al revés: primero la actividad humana, la cual abarcaba entre otras cosas la propia construcción de la estructura física, y sólo en segundo lugar dicha estructura. Metonímicamente unifica cada uno también en la metáfora que es el pronombre «yo» la sucesión de hechos que constituyen su historia personal, utilizando el cuerpo como lugar. «Yo» expresa la unidad histórica de una serie de sucesos diferentes.

La metáfora es el nombre de un lugar, de un topos, que no es lo mismo que un mero trozo de espacio, sino la confluencia o desembocadura en la que el sentido se establece o encarna. No hay, por eso, nada peor dicho que la frase «El saber no ocupa lugar», pues lo que el saber no ocupa es espacio. Aristóteles hace de los lugares, topoi, un concepto central de la retórica, equivalente a los axiomas de la lógica. Los lugares son la opinión, la experiencia y los valores compartidos, los puntos de coincidencia de sentido que nos permiten entendernos y convencernos unos a otros e incluso, en general, hablar. Pues para comunicarse no es suficiente con un sistema de significantes. Es necesaria una plataforma común de sentido y hábitos de expresión, un arsenal en que la inventiva o inventio se apoya para hilar su discurso.

Tampoco el lugar histórico se reduce a un mero emplazamiento físico, pues su constitución reside en los sucesos. La ironía del urbanismo moderno reside en una sucesiva destrucción de lugares con la pretensión construir otros nuevos, sin a menudo lograr otra cosa que construir meros espacios. La sombra irónica de Edipo - el alguacil alguacilado que atribuyéndose el papel de justiciero al final resulta ser el propio homicida buscado - se cierne sobre nuestros políticos y nuestros ingenieros sociales. La ironía es un bumerang.

Si en lugar de quedarnos al nivel objetivo o sustantivo de los tropos de la retórica tradicional, buceamos en el reino mental de la construcción del mundo, la metáfora y la metonimia se nos dibujan como una encrucijada conceptual. Pues de modo semejante a la visión de Constantino el Grande cuando se le apareció en el cielo una cruz con el emblema «In hoc signo vinces» («En este signo vencerás»), una vez superado el nivel de los tropos retóricos, podemos imaginarnos una cruz cuyo eje vertical es la metáfora y el horizontal la metonimia, con un emblema que reza: «In hoc signo vides» («En este signo bien verás»). Al tratar, hace un par de años, de estudiar los dos tropos o figuras como esquemas o signos para entender la función del lenguaje, fui vislumbrando un nuevo esquema en el que el carácter figurativo se iba diluyendo para dejar paso a otro más profundo. Lo cual superaba, sin hacerlo inútil, el camino seguido hasta entonces, como el montañista que contempla desde la elevada meta la trayectoria recorrida. No se trataba de que las figuras retóricas consideradas como tales sean un error. Pero la concepción retórica habitual de ellas no es más que una etapa provisional de su adecuado entendimiento, 
de una comprensión más profunda. Sin abordarlas primero como figuras o tropos no habría yo llegado a entrever su encrucijada oculta. Lo cual en sí es una ejemplificación de lo que son el Signo, la Representación y el Conocimiento: un descubrimiento paulatino que rima perfectamente con la concepción griega de la verdad como alezeia. Las figuras retóricas en sí no explican nada o lo explican a medias, pero su presencia anuncia un fondo oculto que urge su explicación.

Metáfora y metonimia son, pues, dos aspectos de una mecánica creadora. La metonimia representa su elemento dinámico, que busca y colecciona, y la metáfora el ancla que «limpia, fija y da esplendor», eligiendo la palabra adecuada, como nuestra ilustre Real Academia. La relación entre Metonimia y Metáfora es como la existente entre realidad e imaginación o entre inteligencia y voluntad. La metonimia y la metáfora son inseparables una de otra y pierden su valor cuando se las divorcia. Un estudio de la metáfora separado de la metonimia, como hacen Lakoff y Johnson ${ }^{16}$ o como hizo Sterner ${ }^{17}$ y otros que confunden metáforas con metonimias, no supera el nivel del tropo retórico, quedándose sólo a las puertas del entendimiento de la creación lingüística.

Precisemos. A nivel objetivo, como usos o ejemplos concretos, metáfora y metonimia se distinguen mutuamente. A nivel psíquico, como actividades mentales, son inseparables, aunque tampoco confundibles.

\section{La ironía del concepto}

Escarbando en el paradójico fenómeno de las desviaciones lingüísticas de sentido descubrimos el mecanismo de la creación y articulación de conceptos. Ya la Escolástica distinguía entre concepto formal y concepto objetivo, separando el acto mental de su producto. Escalada la vertiente montañosa del concepto de la ironía, vislumbramos la vertiente antes oculta de la ironía del concepto. ¿Qué revela esa incompatibilidad entre lenguaje y sentido y esa paradójica necesidad de unirlos? Consideremos la íntima relación existente entre lenguaje, sentido e ironía.

Se nos ha inculcado que todo lenguaje racional sigue las normas de la lógica formal. Pero la Lógica y el principio de no-contradicción son solamente válidos en un sistema de significantes escuetos, en un decir como simple decir, cuyo modelo es la matemática o la ciencia positiva. Entre el decir y su sentido la discrepancia y la ambigüedad son constantes. El mero lenguaje como producto o estructura (ergon) jamás haría posible la comunicación sin el lenguaje como

${ }^{16}$ George Lakoff y Mark Johnson, Metáforas de la vida cotidiana, trad. de Carmen González Marín, Cátedra, 1991. De los mismos autores acaba de aparecer la voluminosa obra The philosophy in the flesh, Basic Books, Nueva York, 1999, donde se desarrollan de una manera interesante las ideas de otro libro de Mark Johnson, trad. al español por Horacio González Trejo: El cuerpo en la mente, Editorial Debate, 1991.

${ }^{17}$ Gustaf Sterner, Meaning and Change of Meaning, Indiana Univ. Press, 1931. 
actividad (energeia). Y aunque un león pudiera hablar — decía Wittgensteinno lo entenderíamos. El entendimiento entre humanos a través de los signos y del discurso se debe a que el ser humano trasciende al mundo fenoménico y físico y además participa de un ámbito común a los otros seres humanos. Sometidos al mundo corporal y a los signos del lenguaje que utilizamos, son éstos por sí solos incapaces de expresar el sentido de nuestra existencia. Pero para encarnarse en la historia humana, ese sentido no tiene otro camino que lo corporal y los signos.

El hombre se hace un hombre dentro de una comunidad humana, encarnando y desarrollándose a través del cuerpo y del lenguaje. He aquí la tragedia o la ironía de la existencia humana: la compulsión a un paradójico quehacer. Wittgenstein, que había entendido esto perfectamente, acercándose mucho a Kierkegaard en sus comentarios sobre ética y religión, decía en el Tractatus que de aquello que no podemos hablar es necesario que callemos. El mundo objetivo de los hechos era el único ámbito del que el hablar era posible. En cambio, hablar de ética o de religión, hablar del sentido de la vida humana, «es arremeter contra los límites del lenguaje»y, por imposible, renunciable. «Este arremeter contra las paredes de nuestra jaula es perfecta y absolutamente desesperanzado», decía ${ }^{18}$. Lo cierto es, sin embargo, que la existencia humana transcurre en un constante hablar justamente de aquello de lo que en principio no podemos hablar. Kierkegaard diría, que, en sentido estricto, no nos es posible hablar absolutamente de nada. Ni siquiera de los hechos que componen el mundo objetivo. Pero nuestra condición humana consiste justamente en vernos forzados, a hacer eso que es imposible. En ello se funda propiamente la libertad humana. Hegel lo denominaba astucia de la razón. El hombre es el ser que se sale con las suyas obedeciendo las condiciones que se le imponen. Bacon decía lo mismo desde la perspectiva opuesta: «Natura nisi parendo non vincitur» (Sólo se vence a la naturaleza obedeciéndola). Lo que eleva al hombre por encima de la naturaleza viviente es, al mismo tiempo, una capacidad y una exigencia de transformar en posibilidad lo que en principio se presenta como necesidad; como el prisionero que, en su fuga, hace de las sábanas y los muros de la propia cárcel el instrumento de su libertad. El proyecto, hoy perfectamente realizable, de una cárcel en que la evasión sea absolutamente imposible, no se pone en obra - según nos decía el director de un centro penitenciario danés - porque la vida de los reclusos perdería totalmente su sentido si la posibilidad, siquiera remota, de la fuga no alentara en sus mentes. Y encerrado en aquella sórdida e inhumana mazmorra del convento toledano, el más grande de nuestros místicos, San Juan de la Cruz, concibió (imaravillosa ironía!) las palabras más bellas y más llenas de sentido, aquellas palabras de La noche oscura del alma. Su evasión espiritual precedió incluso a su huida física y quizá incluso la inspiró.

${ }^{18}$ Ludwig Wittgenstein, Conferencia sobre ética, trad. de Fina Birulés, Univ. Autónoma, Barcelona, Paidós, 1989. 
El sentimiento trágico de la vida es la ironía kierkegaardiana. Para el filósofo danés se constituye el sujeto individual humano como una paradójica articulación de lo infinito con lo finito, de lo trascendente y lo contingente ${ }^{19}$. La ironía supone la exigencia existencial de conjugar dos ámbitos mutuamente incomensurables. Escindido entre dos reinos incompatibles, el ser humano sólo puede consumar su humanidad asumiendo la paradoja de su existencia, no tratando de resolverla o evitarla. La dialéctica kierkegaardiana es, como dice Torsten Bohlin, una dialéctica cualitativa propia de la existencia individual, por contraste con la dialéctica cuantitativa de raíz hegeliana ${ }^{20}$.

La concepción moderna, ontológico-positivista, según la cual el lenguaje siempre describe o representa un algo objetivo, induce a Wittgenstein a negar (si bien respetuosamente) no la ética, sino el sentido de la ética y de todo aquello que trasciende al mundo de los hechos constituyendo un ámbito de valores. En Aristóteles, sin embargo, encontramos (iquién iba a decirlo!) una concepción radicalmente diferente de la razón y del lenguaje. En un párrafo de la Política, a menudo leído y rara vez justamente valorado, nos dice Aristóteles que la razón por la cual el ser humano, en mayor grado que ningún otro animal gregario, como la abeja, puede ser llamado animal social, es porque tiene logos. Y tiene logos, según el filósofo, no por su capacidad de expresar lo que siente, que eso también lo hacen a su modo los animales; pues éstos emiten meros sonidos, pero los hombres, gracias al $\log o s$, tienen la facultad de emitir palabras. Y ese logos que es el don de la palabra, consiste en poder distinguir, dice el texto aristotélico lo justo de lo injusto y lo bueno de lo malo ${ }^{21}$. No habla de distinguir «lo verdadero de lo falso», como quizá era de esperar, sino lo justo de lo injusto. Párrafo éste alucinante y sorpresivo. Aquello que la concepción moderna de la razón quiere desterrar de ella es, según el texto aristotélico, justamente lo que la justifica. La razón aristotélica por antonomasia no es la razón teórica, sino la razón práctica. Pero ni siquiera una razón práctica en el sentido moderno de la palabra «práctica», que supone una actividad dirigida por su fin o resultado, sino un obrar que tiene sentido en sí mismo y da sentido último también al hacer finalista y a su resultado.

El problema de Wittgenstein y del pensamiento occidental moderno es la reducción por metonimia de la acción a su sujeto o a su resultado, convirtiendo el sentido verbal en sustantivo gramatical. El sentido se concibe así como una esencia que constituye objetivamente las cosas del mundo; el lenguaje se identifica con las palabras y la ironía con las expresiones bizcas de sentido. Pero hacer eso es nombrar los signos, no hablar de lo que los signos revelan. El sentido, el lenguaje, la ironía no son ergon, sino energeia, no son algo producido,

${ }^{19}$ Søren Kierkegaard, Afsluttende uvideskabelig Efterskrift («Samlede værker» 9 \& 10 bind), København, Gyldendal, 1982.

${ }^{20}$ Torsten Bohlin, Sören Kierkegaards etiska åskådning, med särskild hänsyn till begreppet «den enskilde». Ak. avh., Stockholm, Diakonistyrelsens bokförlag, 1918.

${ }^{21}$ Aristóteles, Política, ed. bilingüe de María Araujo y Julián Marías, 2. ${ }^{\text {a }}$ ed., 2. ${ }^{\text {a }}$ reimpr. Madrid, Centro de Estudios Constitucionales, 1989 \{1253a\}. 
sino la fuerza que produce y otorga ser. Una concepción que recuerda a la de Wilhelm von Humboldt ${ }^{22}$. Decir que el lenguaje son las palabras, que el sentido es la esencia independiente y objetiva de las cosas y que la ironía es la expresión de sentido desviado y sobreentendido, son formas secundarias y derivadas de hablar, pura desviación metonímica. Las palabras no son propiamente el lenguaje, sino el instrumento de su actividad expresiva, siendo las expresiones lingüísticas el resultado de esa actividad. El sentido es propiamente el acto de iluminación y colorido mental que da el hombre a las cosas para engarzarlas en el mundo humano. Y la frase de sentido torcido o el final trágico no son propiamente la ironía, sino el testimonio, respectivamente lingüístico e histórico, de que la existencia humana es un puente tendido sobre un abismo infranqueable.

\section{La encarnación del espíritu y la ironía del sentido}

Ironía, lenguaje y sentido son gramaticalmente sustantivos pero enmascaran, como muchas otras palabras, un significado cuya expresión adecuada sería el verbo. A pesar de que «verbo» significa etimológicamente lo mismo que «palabra», lo cual haría de él la palabra o categoría gramatical por antonomasia, es notable cómo las lenguas occidentales otorgan al sustantivo la hegemonía del discurso y el trono de la lengua. Es la herencia ontológica de Parménides y Platón. Todo aquello que en propiedad cabría expresar en forma verbal se transforma metonímicamente en sustantivo. Incluso la propia palabra «palabra». Pues unas veces significa ésta lo que el hombre hace, la facultad de hablar, el verbo. Otras el material del lenguaje, los elementos estructuradores, la categoría de sustantivo.

Al predominio occidental del sustantivo corresponden paralelamente la prioridad del cuerpo sobre la mente, de la materia sobre el espíritu, de la teoría sobre la praxis, de la lengua (Langue) y la escritura sobre el habla (parole), del significante sobre el significado, de la vista sobre el oído, de la geometría sobre la historia, del espacio sobre el tiempo, de la ontología sobre la generación, de la cosa sobre la acción, de lo masculino sobre lo femenino y de la metáfora sobre la metonimia.

Ese ontocentrismo o falocentrismo de la mentalidad occidental, reifica y sustantiva todas las actividades humanas y el propio concepto de actividad. Toda actividad se convierte así en el ergon de la norma estipulada. Confundimos entonces la democracia, que es una forma de vida, con el parlamentarismo

\footnotetext{
${ }^{22}$ Wilhelm von Humboldt, Sobre la diversidad de la estructura del lenguaje humano y su influencia sobre el desarrollo espiritual de la humanidad, trad. y prólogo de Ana Agud, Anthropos, 1990. Véanse también: Wilhelm von Humboldt, Escritos sobre el lenguaje, ed. y trad. de Andrés Sánchez Pascual con pról. de José María Valverde, Península, 1991, así como: Leo Weisgerber, Dos enfoques del lenguaje-«Lingüística» y ciencia energética del lenguaje, trad. de Isidoro Pesonero del Amo, Gredos, 1979.
} 
que es un código de reglas de juego. El poder, que es una forma de obrar, se convierte en algo mítico, en un atributo. Y la libertad, convertida en un fin u objetivo alcanzable, da lugar a esos contradictorios movimientos de liberación que hablan de un camino hacia la libertad y lo allanan pasando por encima de cadáveres sin cuento, como si la libertad fuera la meta y no el camino mismo. Esta ceguera conceptual ha conducido a una disyuntiva ética que unas veces subordina la acción a su resultado y otras a una regla preestablecida. En esta perspectiva, la ética política aristotélica, en la que la bondad del obrar se genera en su propio ejercicio, resulta totalmente incomprensible para una Polis moderna cada vez más menesterosa de esa virtud ciudadana que reclamaba el filósofo.

La búsqueda del sentido de la ironía conduce a la inquisición sobre la ironía del sentido. Y como el sentido se confunde unas veces con el significado y otras con la finalidad, me voy a ver obligado a decir algo acerca de esa relación conceptual, para lo cual resulta inestimable la semántica aristotélica. No deja de ser una ironía que, un filósofo que tan poco supo apreciar lo que significa la ironía, sin embargo, nos haya proporcionado las mejores herramientas para comprenderla.

La palabra castellana «sentido» no es una metáfora muy afortunada. La sueca mening o la inglesa meaning son más apropiadas al uso a que nos estamos refiriendo. Además, meaning mantiene su proximidad al verbo to mean, mientras que «sentido» $\mathrm{y}$ «sentir» se hallan divorciados. La palabra española «sentido», como designativa de nuestra actividad mental valorativa, ha quedado totalmente sustantivada. Debo por eso hacer tanto más hincapié en que hablo de sentido primordialmente como una fuerza creadora - presente no sólo en el lenguaje, sino en toda obra de creación humana - que da inteligibilidad y coherencia al mundo contingente en que el ser humano, que es mente, logos, se halla encarnado.

En lenguaje ordinario llamamos «sentido de algo» solamente al producto de esa creación de la mente humana. Pues el sentido se encarna en las cosas - tanto en las ya existentes como en las que el hombre mismo va creandohaciéndolas significativas. La cultura no es sino una articulación y transformación de la realidad corpórea y finita por obra del sentido. Donde se agotan las cosas, lo perceptible y sensorialmente demarcable, crea el hombre una esfera cristalina de palabras, que son también cosas artificiales, mucho más fáciles de usar para fines diversos que las cosas tangibles. Con el material de las palabras, construye el hombre un mundo de instituciones y relaciones inmateriales. Si el hombre da sentido a la realidad mundana y a las palabras es porque el sentido no son las cosas ni las palabras mismas, ni reside en ellas. La actividad de dar sentido, atravesando el ventanal de vidrio del lenguaje, va propiamente dirigida, como quería Wittgenstein, al mundo de las cosas. Pero una vez creado y desarrollado el lenguaje como sistema de palabras, lo aplica el hombre también para volverse hacia fuera del mundo, hacia sí 
mismo y hacia el propio lenguaje, designando incluso aquello que propiamente no es designable: Dios, lo ético, el sentido de la vida. Lo así significado no es carente de sentido, como Wittgenstein (por cierto, con poca convicción) pretendía. No se trata de que un hablar de lo trascendente carezca de sentido, pues lo que trasciende al mundo es el propio sentido, la fuerza creadora que da significado a las cosas del mundo. Su sentido no puede expresarse porque es él mismo el que crea la expresión. Y toda expresión lingüística ha sido desarrollada con base en el mundo corporal apoyado en la imaginación, siendo también las palabras abstractas acerca de los hechos del mundo, aplicaciones metafóricas que hacen de toda realidad una realidad en cierto modo sensible, visible y tangible, o por lo menos imaginable como tal.

La metáfora se basa siempre, en último término, en la identificación imaginativa con algo anteriormente visto o tocado. Las descripciones de los místicos («la noche oscura», «la casa», «la llama de amor viva») son expresiones metafóricas que no ponen ya en relación dos cosas comparables, sino que son la manera de denominar lo inefable en términos mundanos, para hacerlo de algún modo inteligible y comunicable. La metáfora mística utiliza una imagen recogida en el mundo, carente de objeto de comparación: un significante sin significado detectable. De manera semejante a los significantes musicales, su significado no es explicable en ningún lenguaje. Pero también los significantes intramundanos, en los cuales apoyamos el sentido que damos a las cosas y a los hechos, son productos de un cajón de sastre figurativo que hemos ido formando con anterioridad y que ya nuestros padres nos entregaron repleto. Los nombres que proyectamos sobre las cosas, nos hacen creer que entendemos lo que son las cosas mismas, cuando en realidad no hacen sino apresar y dar color determinado al propio sentimiento de nuestro estar-en-el-mundo. Creemos que hablamos de las cosas cuando son más bien las cosas las que hablan de nosotros.

\section{Sentido y significado}

La ironía es concebida, dijimos, como la tensión de un ser que es al propio tiempo mente y cuerpo, espíritu y materia, infinitud y contingencia. Esa tensión trata de dar sentido al mundo corporal desde el mundo mental, sin propiamente conseguirlo. Mejor dicho, trata de utilizar el mundo corporal como la matriz en que el sentido engendra su expresión. Por ello el quehacer de la vida es el hacer la vida y al preñar de sentido al mundo realiza el hombre su propia historia y su propio sentido.

La encarnación de Cristo personifica, en la narración religiosa, la ironía de la existencia. Dios hecho hombre es el símbolo más expresivo del sentido de la ironía. Wittgenstein tenía razón al afirmar que la ética, como lo absolutamente valioso, no puede ser una ciencia. Pero sería no menos desatinado creer que la ciencia describe la realidad, gozando de sentido objetivo. La metonimia categorial, transformadora de lo verbal en sustantivo, no es más que 
una expresión omnipresente de nuestra condición humana de seres espirituales hechos carne y hueso. Por algo llamamos Verbo al Hijo de Dios. «Que aquí existe una conexión - decía Wittgenstein, según testifica $\mathrm{F}$. Waisman ${ }^{23}$ - lo han sentido y expresado los hombres de este modo: Dios Padre creó el mundo, mientras que Dios Hijo (o la palabra procedente de Dios) es lo ético. Que los hombres hayan dividido la divinidad para después unirla de nuevo, indica el hecho de que aquí hay una conexión.»

La creencia en un sentido objetivo y sustantivo es el presupuesto de toda ontología. Pero el sentido, para serlo, tiene que ser algo inspirado desde fuera de la realidad mundana que otorga a cada cosa su cualidad, aunque las cosas no lo merezcan (que en eso reside la ironía). La creencia ontológica en un sentido que habita las cosas mismas y engendra a su vez la ilusión de una ciencia objetiva de la realidad en sí, se debe a la confusión entre el hacer y el obrar y entre el sentido y la finalidad. Toda ontología es en principio atea, a pesar de sus simulaciones.

Sentido y significado se toman a menudo como términos sinónimos. Otras veces se habla del sentido como de la finalidad de algo. El sentido es además el nombre de los órganos con que percibimos el mundo exterior y de la dirección en que algo se mueve. Por si era poco tenemos la palabra «sentimiento» y el ambiguo verbo «sentir» que crean un campo semántico abigarrado. Advirtamos ahora la relación de «sentido» con «finalidad», por un lado, y con «significado», por otro. «Significado» $\mathrm{y}$ «finalidad» se presentan como denominaciones de algo estrictamente objetivo, mientras que «sentido», sin ser verbo, se deja más fácilmente asociar a una actividad.

La vida del individuo humano se desenvuelve en la encrucijada de una actividad (una energeia) que es la mente o, si se quiere, el sentido, y una realidad material en la que ese sentido se encarna. No hay una sustancia pensante y otra extensa, hay la conjunción de una actividad y una realidad (en el sentido lacaniano de «lo real»). Conjunción ontológica y paradójica de la que surgen tanto el sujeto como el objeto. El verbo, que es el sentido, la actividad, la mente, crea las palabras, el signo (ergon). Los objetos del mundo se constituyen en perchas del sentido y con los sonidos que emite constituye el hombre fonemas y palabras significativos. Lo que en el fondo sea ese mundo real al que la mente se enfrenta, es inútil dilucidarlo. Hasta nuestro propio cuerpo es un extraño. Lo único que el hombre entiende es lo que él mismo ha hecho (factum verum).

Esa coadunación, que tanto ha preocupado a los filósofos, de dos realidades totalmente heterogéneas, es tan incontrovertible como inexplicable. La existencia humana está irremediablemente anclada en una paradoja y su única forma de existencia es la ironía que consiste en vernos compelidos a utilizar categorías materiales y finitas como signo de algo que las desborda, dando

${ }^{23}$ En Lectures and conversations, trad. francesa «Leçons et conversations sur l'esthétique, la psychologie et la croyance religieuse», Paris, Gallimard, 1971. 
lugar a una manera indirecta e impropia de entender. La caída en la tentación objetivista y en la arrogancia de la verdad concebida como correspondencia dan origen a la ontología y a la ciencia positiva. Tratar de trascender lo finito, lo material y lo sígnico, colocándonos imaginativamente más allá de la ontología, como si nos levantáramos a nosotros mismos de los pelos, es una actitud metafísica cultivada en las filosofías orientales. En nuestra cultura, quienes más se han acercado a una inteligencia de este problema metafísico serían quizá Fichte y, sobre todo, su homólogo sueco Benjamin Höijer, si no fuera por su vocación demasiado sistemática y monista. Mas lo que yo busco no es tanto una metafísica cuanto una metapsicología.

En el mundo y en el lenguaje encuentra y elige el individuo humano la forma de expresión que ha de realizar el sentido de su propia existencia. Las alternativas son incontables. Pero su —en principio ilimitada-libertad creadora se ve delimitada por las condiciones materiales del mundo y por el sistema de significaciones establecidas por la cultura. El individuo humano tiene que aceptar las leyes de la materia y nace ya dentro de una tradición cultural determinada. Las condiciones naturales y los usos de los hombres que le han precedido aportan los instrumentos con los que el individuo hace su vida y determinan el escenario en que ésta ha de desarrollarse. Toda herencia supone simultáneamente libertad y determinación, posibilidad de actuar y elegir unida a norma y limitación. Sin esos elementos necesariamente impuestos, la vida humana individual carecería, sin embargo, de toda posibilidad de realizarse. Sin unas normas sociales y un sistema preexistente de significantes marcados por su uso, desaparecería el individuo humano. Y llamo individuo humano, no a un cuerpo animado y abstracto, sino al ser concreto que está siendo mientras hace su historia. El hombre no es sustancia ni naturaleza, sino actividad e historia.

La sociedad humana se constituye a base de relaciones de sentido en las que nos valemos de significantes cuyos usos acumulados permiten la continuidad de las generaciones. Esos usos acumulados son los significados propiamente dichos. He aquí, pues, una posibilidad de distinguir el significado del sentido. El significado es algo objetivado y común perteneciente al orden social. El sentido es la actividad informante, mediante la cual los individuos humanos activan esos significados en situaciones concretas y en discursos específicos. El lenguaje no es ni totalmente arbitrario ni totalmente libre. Puedo usar de diferentes maneras las palabras que he aprendido, pero no puedo usarlas de cualquier manera. La retórica aparece así como la virtud o arte de activar y crear expresiones, más o menos acertadas, más o menos brillantes, para comunicarnos (para hacer patente nuestra comunidad) con otros hombres. La posibilidad de entendernos a través del lenguaje no reside en las palabras mismas, sino en el hecho de que, siendo seres humanos, pertenecemos a un mundo común de sentido. Nos entendemos a pesar de que las palabras son incapaces de canalizar el chorro del sentido. Hablar es como coger agua con 
las manos, pero «a buen entendedor con pocas palabras basta». A un león no le entenderíamos aunque pudiera hablar.

Esa comunidad de sentido que es la comunidad de un destino y unos valores, se expresa en la palabra griega pistis (origen de la latina fides: la fe, la fidelidad, el crédito, la confianza, la familiaridad con algo, el reconocimiento) que es el eje conceptual de la Retórica de Aristóteles. La propia mentira, que es la ironía vuelta del revés, sería imposible si la comunicación no echara sus raíces en el terreno de la confianza. Ser hombre supone pertenecer a una comunidad de sentido que nos hace entendernos y creer, aunque hablemos desviadamente, y aun cuando nuestra intención sea aviesa.

La confianza original puede, sin embargo, deteriorarse o fortalecerse. Sin confianza no hay vida social y la misión fundamental de la política es fomentarla. La tragedia de España, si se la compara con la sociedad sueca, por ejemplo, ha consistido y está volviendo a consistir en la destrucción de la confianza. Los políticos modernos creen que su tarea es hacer cosas. «La política es cuestión de actuar y de obtener resultado», declaraba con orgullo hace poco una de las nuevas figuras del socialismo sueco. iDios nos coja confesados! Una visión aristotélica de la política nos enseña que la misión del político reside sobre todo en el buen ejemplo, que fomente la confianza en las instituciones y en su buen funcionamiento. Pues con confianza sobran las reglas, pero sin ella no hay reglas que basten.

La ironía no consiste simplemente en la incompatibilidad entre lo trascendente y lo finito de que hablaba Kierkegaard y en la incongruencia entre una actividad espiritual y un mundo de cosas materiales. La ironía está a la base del lenguaje mismo, por la sencilla razón de que cada acto de expresión se realiza ante una situación totalmente nueva y única, a partir de significantes usados con anterioridad y portadores de un significado general. Solamente un lenguaje que creara sus palabras para cada situación concreta, sería capaz de expresar su sentido directamente. Pero entonces dejaría automáticamente de ser lenguaje, ya que un signo que se agote en un uso único y no tenga la capacidad de ser usado repetidas veces, no es signo. La significación se establece a base de una operación mental que reduce una infinidad de casos semejantes a sus rasgos más comunes, constituyendo así su concepto abstracto. Todo concepto supone así al propio tiempo un empobrecimiento y una posibilidad. El hombre se expresa ante las situaciones y las cosas que van apareciendo en el tiempo, recurriendo a los conceptos acumulados que le parecen adecuados, no sin remendarlos constantemente, haciéndolos adaptarse a nuevas condiciones de uso. El espíritu más creador es el que sabe encontrar posibilidades inusitadas en los instrumentos que se le ofrecen. Hablar es siempre, sin embargo, vestirse con ropas de segunda mano.

La transición mental que, de los casos concretos de la experiencia, crea un concepto válido en general, es un proceso fundamentalmente metonímico en el que la metáfora actúa como ayudante. Y la utilización del concepto 
acuñado para expresarnos ante la situación concreta, es un proceso dirigido por la metáfora con la ayuda de la metonimia.

Pretender que la ciencia positiva dice la verdad sobre lo que sucede en el mundo es absurdo, pues no hay ciencia de lo particular, sino de lo general, y sólo lo particular sucede de hecho. El lenguaje en que se expresa la ciencia es un cajón de sastre del que nos servimos para, sesgadamente, irónicamente y a distancia, explicar lo que pasa. El lenguaje que trata de hablar de lo que realmente pasa, participando en el propio hecho que expresa, es el lenguaje cotidiano y retórico, declaradamente irónico e indirecto. La mayor ironía de todo esto es, no obstante, que el lenguaje que más se distancia de todo, el lenguaje científico, siendo más irónico que ninguno, logre arrogarse el monopolio de la exactitud y la verdad. La diferencia entre la narración literaria y el texto científico reside en que la primera enseña fingiendo y el segundo finge enseñar.

Antonio Machado trataba de contraponer a los universales de la razón unos universales del sentimiento, que serían la base de la poesía. Y Pascal hablaba de las razones del corazón que la razón no entiende. Encuentro yo un dualismo entre los conceptos universales de la razón teórica y lo que yo llamaría los universales del sentido, alcanzables por la razón práctica. Los conceptos se forman por la vía teórica de la inducción y tienen como resultado el significado que se aplicará a priori, como una norma. El sentido se intuye a través de los ejemplos vividos, sin pretender ser formulado en palabras, como los significados. Los significados se acumulan para usarse; el sentido se asimila para actuar en la aplicación de un significado a una situación concreta.

\section{Sentido y finalidad}

Lo que el mundo moderno llama «práctica» no es más que una aplicación instrumental de la razón teórica constitutiva de la mentalidad tecnológica. Es esencial en esa mentalidad la reducción del sentido a la finalidad. La Ética de Aristóteles nos permite reconstruir una distinción para la que nos hemos quedado ciegos. Distingue él entre un «obrar» (verbo intransitivo) que tiene su sentido en sí mismo y llama praxis y un «hacer» (verbo transitivo) cuyo sentido reside en la finalidad prevista, llamado poiesis. La mentalidad moderna reduce toda praxis a poiesis y da al conjunto formado por ambos el nombre de la vieja praxis. En esta simbiosis conceptual tiene lugar la confusión del sentido con la finalidad.

En un pasaje de la Ética que ha dado ciertos quebraderos de cabeza, al referirse a la deliberación (boulesis), dice Aristóteles que no se delibera acerca del fin, sino acerca de los medios. La palabra traducida como «fin» no es otra que la griega telos. A mi juicio, lo que Aristóteles quiere significar con telos es lo que nosotros llamamos «sentido», palabra que sólo metonímicamente puede reducirse a «fin». Pues el fin es algo que aparece al límite de una 
trayectoria, mientras que el sentido es aquello que inspira los momentos de ella, moviéndonos a elegir un medio u otro, un camino u otro. Si el sentido de la vida humana fuera el fin de ella, nuestro sentido se realizaría sólo con la muerte. Esa confusión está a la base del Ser-para-la-muerte del existencialismo. Sería desde luego una ironía de la existencia el que nuestra vida tenga que haber llegado a su negación para alcanzar su sentido. Pero el sentido no es un objeto a alcanzar, sino aquello que alumbra cada oportunidad (kairos) y cada elección de nuestra existencia.

Es cierto que nuestra vida puede descomponerse en tramos finalistamente analizables. Viajo desde Estocolmo hasta Madrid u otra ciudad española para participar en un seminario leyendo una conferencia. Para ello he tenido que escribirla previamente. Ahora bien, ¿por qué doy esa conferencia? ¿Será por la cuantía de su remuneración? Dudosamente. ¿Por la vanidad del honor de ser escuchado y, quizá, alabado? Es posible. ¿Por la satisfacción y felicidad que el hacerlo supone?... Esta última pregunta no busca ya el porqué instrumental de un hacer, sino el sentido de un obrar. Elegimos medios para llegar a una meta, pero todavía cabe preguntarse qué sentido tiene esa meta perseguida, cuál es el telos de esos fines.

En un hacer instrumental la idea del objeto concreto o meta perseguidos alumbra ciertamente la elección de los medios materiales, pues todos aplicamos las técnicas que conducen al fin propuesto. Pero lo que unifica a todos los segmentos finalistamente analizables y a las metas perseguidas en cada uno de esos segmentos existenciales, es algo profundo e inexplicable que constituye el sentido de nuestra vida. Todo lo que hacemos lo hacemos para realizar ese sentido, arrepintiéndonos o regocijándonos de lo ya realizado, según se identifique o no con nuestra aspiración de vida. El criterio unificador de todo lo que hacemos es el sentido. Y, a diferencia de los fines y los medios analizables, ese sentido no puede objetivarse en palabras por la sencilla razón de que es él mismo, como actividad, lo que crea los objetos y las palabras. Él es la palabra, el verbo.

\section{Colofón}

Aquí termina mi discurso de la ironía. He obligado al lector a hacer un viaje no sólo demasiado apretado, sino, para colmo de males, demasiado largo. Mi discurso ha estado lleno de incoherencias, alguna contradicción y mucho lenguaje indirecto. En esto soy consecuente con lo que sostengo y vivo como predico, haciendo lo que digo. El discurso en su totalidad es, en cambio, más problemático, ya que trata de hacer una descripción de la ironía que pretende ser verdadera, al mismo tiempo que sostiene que una descripción objetiva verdadera es imposible. Cometo ahí la ironía de hacer lo contrario de lo que digo, dando además mal ejemplo. Mi discurso de la ironía ha sido una ironía del discurso. La culpa la tienen las reglas impuestas por la circunstancia concreta 
en que tiene lugar. La ironía no es un tema que se ajuste a las formas universitarias y académicas. Enseña más sobre la ironía una representación del Edipo o la lectura del poema épico Aniara de Harry Martinson, que todas las conferencias eruditas o filosóficas. Tomen pues mi descripción de la ironía como un cuento que, ni pretende haber reflejado la verdad literal ni ser el único cuento posible. El que me escucha o me lee sabrá albergar en sí su propia experiencia del sentido de lo que tratamos. 